\title{
Mineral profile and characterisation of cookies made from legume green grain flour
}

\author{
Lucas Costa MAIA ${ }^{1,2}$, Rita Maria Weste NANO ${ }^{1}$, Wagna Piler Carvalho SANTOS ${ }^{1 \star ~(D), ~}$ \\ Pablo Vinícius Borges Silva do NASCIMENTOํㅜ, Katia Elizabeth de Souza MIRANDA ${ }^{3}$, Fábio Santos de OLIVEIRA ${ }^{4}$
}

\begin{abstract}
The aim of this work was to determine and compare the mineral composition and physico-chemical parameters of formulations of cookies developed by hand based on Lablab purpureus (L.) Sweet (mangalo-BFM), Vigna unguiculata (L.) Walp. (cowpea beans-BFC) and Cajanus cajan (L.) Huth (pigeon pea-BFP) flours. The results indicate that the cookies have a high content of essential minerals (mainly $\mathrm{K}, \mathrm{P}$ and $\mathrm{Ca}$ ). Moisture (4.48-8.44\%) was below the maximum value established by Brazilian legislation, and lipids (6.35-6.56\%) and ash (3.33-3.96\%) were like products found in the market and literature. High levels of protein (8.37-9.28\%), fibre (3.88-6.39\%) and carbohydrates (66.28-71.19\%) give the product high nutritional potential. No oxidation products were detected. Water activity and acidity remained satisfactory for good food preservation for 45 days. Sensory evaluation indicates a satisfactory acceptability for the BFM and BFC (overall quality above 7). The desirability data indicated that the BFC obtained the best performance for the chosen parameters. Therefore, the elaborated cookies have high nutritional quality and the pulse flour has potential for the enrichment of food products.
\end{abstract}

Keywords: pulses; essential elements; desirability function; ICP OES.

Practical Application: The developed and evaluated cookies made from legumes have a high nutritional content.

\section{Introduction}

Pulses are an important source of nutrients, and their daily consumption is recommended for a balanced diet (Bessada et al., 2019). The presence of many bioactive substances, essential minerals and other compounds confers their nutritional importance (Shahidi \& Ambigaipalan, 2015; Afshin et al., 2014), that has stimulated the development of food made with this unconventional component to make them more nutritious (Wrigley et al., 2016).

In this context, nutritious, low-cost and easily prepared cookies made from cowpea, mangalo and pigeon pea flour were developed and compared in this study. These pulses are traditionally grown and consumed in the state of Bahia, Brazil, and their use in the development of food products represents not only the appreciation of local culture but also an opportunity to encourage family farming.

Many bakery and confectionery products are used as a means for the incorporation of nutrients. Among these, cookies stand out for the technological facilities that allow them to have a wide variety of ingredients as well as long shelf life, good acceptability, low manufacturing cost, ability to be eaten anywhere and serving as a valuable source of instant nutrition (Davidson, 2018; Park et al., 2015).

This work aims to evaluate the mineral and physico-chemical quality as well as the sensory aspects of three formulations of cookies made with pulse flours produced from Vigna unguiculata
(L.) Walp (cowpea), Cajanus cajan (L.) Huth (pigeon pea) and Lablab purpureus (L.) Sweet (mangalo).

\section{Materials and methods}

\subsection{Instrumentation}

An analytical balance Radwag AS 220/C/2 (Radom, Poland) was used for weighing, and a biomedical freezer Panasonic MDF-U5312 (Kadoma, Japan) was used to store the samples before milling. A microwave oven CEM MARS One Touch (Matthews, USA) was used for sample digestion to determine mineral composition.

To determine the proximate composition, an air circulation oven Fanem 520 (São Paulo, Brazil), fat determinator Tecnal TE-044-8/50 (Piracicaba, Brazil), block digester with temperature controller Tecnal TE-007MP (Piracicaba, Brazil) and nitrogen distiller Tecnal TE-0363 (Piracicaba, Brazil) were used. The moisture was determined in a halogen moisture analyser Mettler Toledo HE53 (Columbus, USA).

For elemental analysis, a Perkin Elmer Optima 7300DV (Waltham, USA) was used, applying the following experimental conditions: measuring power $1,300 \mathrm{~W}$; integration time of signal $1 \mathrm{~s}$; plasma gas flow $15 \mathrm{~L} \mathrm{~min}^{-1}$; auxiliary gas flow $1.5 \mathrm{~L} \mathrm{~min}^{-1}$; nebulisation gas flow $0.70 \mathrm{~L} \mathrm{~min}^{-1}$; pumping rate of sample $0.70 \mathrm{~mL} \mathrm{~min}^{-1}$. 
A colourimeter Konica Minolta CR-400 (Chiyoda City, Japan) was used to determine colour parameters. The analysis of texture was carried out using a Brookfield CT3 Texture Analyser (Brookfield Engineering, Middleboro, USA) operated under the following conditions: pre-test speed $2 \mathrm{~mm} \mathrm{~s}^{-1}$; test speed $0.5 \mathrm{~mm} \mathrm{~s}^{-1}$; probe TA39 and repair TA-BT-KI. The Water Activity Meter Labmaster Novasina (Lachen, Switzerland) was used to determine the water activity $\left(\mathrm{A}_{\mathrm{w}}\right)$ at $25^{\circ} \mathrm{C}$.

\subsection{Reagents, reference materials and standard solutions}

The solutions were prepared with analytical grade reagents and ultrapure water with a specific resistivity of $18.2 \mathrm{M} \Omega \mathrm{cm}$ produced by the Merck Millipore Direct Q 3-UV Water Purification System (Bedford, USA). The glass and plastic materials were decontaminated in a neutral detergent bath at $5 \% \mathrm{v} \mathrm{v}^{-1}$ for $24 \mathrm{~h}$, washed with distilled water, and then placed in a $20 \% \mathrm{v} \mathrm{v}^{-1} \mathrm{HNO}_{3}$ bath for $24 \mathrm{~h}$, rinsed with ultrapure water and air-dried.

The multi-elemental patterns of $\mathrm{Al}, \mathrm{Ba}, \mathrm{Ca}, \mathrm{Cu}, \mathrm{Fe}, \mathrm{Mg}, \mathrm{Mn}$, $\mathrm{Ni}, \mathrm{P}, \mathrm{K}$ and $\mathrm{Zn}$ were prepared from the dilution of standard solutions of $1,000 \mathrm{mg} \mathrm{L}^{-1}$ in acid.

\subsection{Sample collection and preparation}

The pulses came from Cruz das Almas, Bahia, Brazil, from family farming, and were stored frozen $\left(-14^{\circ} \mathrm{C}\right)$ until utilisation. The other ingredients (sugar crystal, rice flour, flaked oatmeal, egg, margarine, vanilla extract, chemical yeast and salt) were purchased on the local market.

To produce the flours, the pulses were heat-treated for enzymatic inactivation; they were soaked in $100^{\circ} \mathrm{C}$ water for five minutes, and then immersed in $5^{\circ} \mathrm{C}$ water for the same period. Subsequently, they were placed in a baking dish and heated in a conventional oven (preheated) to $180{ }^{\circ} \mathrm{C}$. At intervals of approximately 30 minutes, the pulses were ground in a domestic blender. The milling and heating process were repeated four times until a dry, homogeneous and low grain flour $(<500 \mu \mathrm{m})$ was obtained.

The development of the three formulations was performed by using a basic cookie formulation and replacing gluten-containing flours with approximately $26 \%$ of cowpea flour (BFC), mangalo flour (BFM) or pigeon pea flour (BFP), which differ in the type of pulses only. The percentage of pulse flour adopted $(26 \%)$ was the result of omitted preliminary studies based on acceptance. The ingredients were mixed and processed manually using fouet until a batter with characteristic consistency was obtained. The batter was divided into small portions of spherical shapes and taken to a conventional oven preheated to $180^{\circ} \mathrm{C}$ for 30 minutes. The cookies were stored at ambient temperature $\left(28-30^{\circ} \mathrm{C}\right)$.

\subsection{Procedure}

\section{Proximate composition and physical chemical stability}

The ash, proteins, crude fibre and lipids were determined according to the Association of Official Agricultural Chemists (2005). The moisture was determined by a halogen moisture analyser. Carbohydrates were estimated by difference. The caloric value was estimated considering the Atwater conversion factors of $4 \mathrm{kcal} \mathrm{g}^{-1}$ for protein, $4 \mathrm{kcal} \mathrm{g}^{-1}$ for carbohydrate and $9 \mathrm{kcal} \mathrm{g}^{-1}$ for lipids. The acidity, peroxide value and $\mathrm{A}_{\mathrm{w}}$ were determined zero (T0) and 45 (T45) days after preparation of the cookies by neutralisation titration (Instituto Adolfo Lutz, 2008), the method Cd 8-53 of the American Oil Chemists' Society (2017) and a water activity meter, respectively

\section{Sensory evaluation}

The sensory evaluation was approved by the Ethics Committee of the Federal Institute of Bahia, opinion number 1.145.758 and process number 46587315.5.1001.5031. For this study, 60 randomly selected test-takers received a consent form and an acceptance form for the evaluation of six sensory aspects: appearance, aroma, colour, flavour, texture and overall quality, numbered from 1 ('extremely disliked') to 9 ('extremely liked'). The cookies were arranged in the trays in a randomly numbered and coded form.

\section{Colour and instrumental texture}

The colour evaluation was performed instrumentally using a colourimeter for the following parameters established by the Commission Internationale de L'Eclairage (CIE): $\mathrm{L}^{\star} \mathrm{a}^{\star} \mathrm{b}^{\star}$ and $L^{*} C^{\star} h$, where $L^{*}$ is luminosity, $a^{*}$ is the range of colour from red to green, $\mathrm{b}^{*}$ is the range of colour from yellow to blue, $\mathrm{C}^{\star}$ is saturation and $\mathrm{h}\left(\mathrm{Hue}^{\circ}\right)$ is pitch angle formed between $\mathrm{a}^{*}$ and $\mathrm{b}^{*}$. The texture analyses were done with a texturometer for hardness.

\section{Mineral composition}

A mass of approximately $0.5000 \pm 0.0001 \mathrm{~g}$ of the samples was weighed in a Teflon tube. To each tube, $1.6 \mathrm{~mL}$ of $\mathrm{HCl} 37 \%$ $\mathrm{w} \mathrm{w}^{-1}$ and $1.7 \mathrm{~mL}$ of $\mathrm{HNO}_{3} 65 \% \mathrm{w} \mathrm{w}^{-1}$ were added, and the tubes could stand for 30 minutes. Soon after, $1.7 \%$ of $\mathrm{H}_{2} \mathrm{O}_{2} 30 \% \mathrm{v} \mathrm{v} \mathrm{v}^{-1}$ was added to the system. All purchased from Merck (Darmstadt, Germany). The digestion proceeded with heating in a microwave in two stages: 1 st a temperature ramp was used up to $170^{\circ} \mathrm{C}$ for 20 minutes; 2 nd the temperature was maintained at $170{ }^{\circ} \mathrm{C}$ for 15 minutes. The power ranged from 290 to $1,800 \mathrm{~W}$. At the end of the program, the vials could cool to room temperature, the solution was transferred to $25.0 \mathrm{~mL}$ conical tubes, and filled with ultrapure water. The concentration of the elements was determined by the ICP OES (Inductively Coupled Plasma Optical Emission Spectrometry), with conditions described in item 2.1.

\section{Statistical analysis}

The data obtained were analysed using analysis of variance (ANOVA), adopting a level of significance of 5\%, and the contrast between the means was evaluated using the Tukey test, all performed using OriginPro 8 (Miami, USA) software. The comparison of optimum characteristics of these food products requires simultaneous evaluation of several parameters to attain the best condition (i.e., maximum levels of fibre, proteins, ash and minerals and minimum lipids and moisture content). To overcome simultaneous optimisation of several 
response parameters, Derringer \& Suich's (1980) multiresponse optimisation strategy was adopted.

The individual desirability function, $\mathrm{d}_{\text {max }}$ (Equation 1) or $\mathrm{d}_{\text {min }}$ (Equation 2), of each response varable was calculated, considering whether optimisation requires maximising or minimising its value.

$d_{\max }=\left(\frac{y-0.8 \cdot y_{\min }}{1.2 \cdot y_{\max }-0.8 \cdot y_{\min }}\right)$

or

$d_{\min }=-\left(\frac{y-1.2 \cdot y_{\max }}{1.2 \cdot y_{\max }-0.8 \cdot y_{\min }}\right)$

The individual desirability function simply consists of converting each variable to a zero to one scale. For response maximisation, 1.0 is assigned to a value $20 \%$ above the maximum and 0.0 is assigned to a value $20 \%$ below the minimum. On the other hand, to minimise the response, 0.0 is assigned to a value $20 \%$ above the maximum, and 1.0 is assigned to a value $20 \%$ below the minimum. The overall desirability function was obtained using geometry mean of individual desirabilities (Equation 3).

$D=\sqrt[m]{d_{1} \cdot d_{2} \ldots d_{m}}$

Statistical comparisons of Derringer \& Suich's functions (1980) for different food products were carried out using ANOVA and Student's t-test for independent samples with Bonferroni's adjustment. Statistica 12.5 package (Statsoft, Tulsa, USA) was used for statistics calculation.

\section{Results and discussion}

\subsection{Proximate composition and physico-chemical stability}

The results of the proximate composition, acidity and water activity $\left(A_{w}\right)$ are presented in Table 1 .

The moisture contents are below the maximum value established by the Brazilian legislation for biscuits, equal to $14.0 \%$ $\mathrm{w} \mathrm{w}^{-1}$ (Brasil, 1978). Due to the low moisture content, BFC are less susceptible to microbial or chemical activity. Besides food preservation, moisture is an important parameter for product sensory properties (Cauvain \& Young, 2008), and in this case, low values are desirable.

The ash contents are similar to those obtained by Marques et al. (2015) for cookies made with whey protein (25.9 $\mathrm{g}$ whey protein concentrate/100 g). The BFC and BFP showed higher ash contents and differed significantly ( $\mathrm{p} \leq 0.05)$ from the BFM. The higher ash content obtained implies that they contain relatively higher mineral content (Cecchi, 2015).

The protein contents in the cookies were higher than those presented by Cheng \& Bhat (2016) for all their formulations of cookies, except the one with $100 \%$ jering seed flour. The results were satisfactory since the ingestion of protein increases muscle mass and strength (Carbone \& Pasiakos, 2019).

The lipid contents were lower and the fibre contents were higher than those found in studies by Kaur et al. (2017) for cookies made with a mixture of flaxseed flour and wheat flour. A low lipid content has become nutritionally appealing since low-fat diets help weight loss and prevent diseases, including heart disease, high cholesterol and diabetes (Aggarwal et al., 2018).

The high-fibre values are desirable since scientific evidence demonstrates a correlation between a fibre-rich diet and health benefits, including better digestive health and cancer prevention (Prasad \& Bondy, 2019). The BFP showed the highest value of

Table 1. Proximate Composition ( $100 \mathrm{~g}^{-1}$; fresh matter; $\mathrm{n}=3$ ), Caloric value (kcal $100 \mathrm{~g}^{-1}$ ), Acidity index (\%; $\mathrm{n}=3$ ) and Aw (dimensionless; $\mathrm{n}=3$ ) of cookies made from legume flours.

\begin{tabular}{|c|c|c|c|c|}
\hline \multirow{2}{*}{ PARAMETERS } & \multirow{2}{*}{ Period } & \multicolumn{3}{|c|}{ Cookies } \\
\hline & & $\mathrm{BFC}$ & BFP & BFM \\
\hline Moisture & & $4.48 \pm 0.05^{\mathrm{a}}$ & $8.44 \pm 0.05^{\mathrm{b}}$ & $7.73 \pm 0.11^{\mathrm{c}}$ \\
\hline Ash & & $3.95 \pm 0.02^{\mathrm{a}}$ & $3.96 \pm 0.02^{\mathrm{a}}$ & $3.33 \pm 0.02^{\mathrm{b}}$ \\
\hline Lipids & & $6.35 \pm 0.07^{\mathrm{a}}$ & $6.56 \pm 0.20^{\mathrm{a}}$ & $6.35 \pm 0.06^{\mathrm{a}}$ \\
\hline Proteins & & $9.19 \pm 0.07^{\mathrm{a}}$ & $8.37 \pm 0.28^{\mathrm{b}}$ & $9.28 \pm 0.23^{\mathrm{a}}$ \\
\hline Crude fibre & & $4.84 \pm 0.96^{\mathrm{ab}}$ & $6.39 \pm 0.85^{\mathrm{b}}$ & $3.88 \pm 0.65^{\mathrm{a}}$ \\
\hline Carbohydrates* & & 71.19 & 66.28 & 69.43 \\
\hline Caloric value & & 378.67 & 357.64 & 371.99 \\
\hline \multirow{2}{*}{ Acidity index } & T0 & $2.28 \pm 0.05^{\mathrm{aA}}$ & $2.57 \pm 0.25^{\mathrm{aA}}$ & $2.40 \pm 0.23^{\mathrm{aA}}$ \\
\hline & $\mathrm{T} 45$ & $2.31 \pm 0.22^{\mathrm{aA}}$ & $3.67 \pm 0.08^{\mathrm{bB}}$ & $2.71 \pm 0.16^{\mathrm{Aa}}$ \\
\hline \multirow{2}{*}{ Aw } & T0 & $0.327 \pm 0.010^{\mathrm{aA}}$ & $0.518 \pm 0.001^{\mathrm{bA}}$ & $0.472 \pm 0.003^{\mathrm{cA}}$ \\
\hline & $\mathrm{T} 45$ & $0.333 \pm 0.015^{\mathrm{aA}}$ & $0.527 \pm 0.003^{\mathrm{bB}}$ & $0.485 \pm 0.007^{\mathrm{cB}}$ \\
\hline
\end{tabular}

${ }^{\star}$ Calculated by difference; means followed by equal lowercase letters in the rows and uppercase letters in the columns do not differ by Tukey test, at a significance level of $5 \%$; values represent means \pm standard deviation. 
fibre and differed significantly ( $p \leq 0.05$ ) from the BFM. It is claimed that the BFP is "high in fibre" as it contains at least $6 \mathrm{~g}$ of fibre per $100 \mathrm{~g}$ according to the European Union (2006).

The high carbohydrate levels give the product a high caloric value. The cookies presented high-density energy, defined as the amount of energy in a given weight of food (Ledikwe et al., 2006). This feature is desirable for athletes and highly exercise-trained individuals as it helps to provide enough energy to fuel health, activities of daily living and exercise workouts (Howe et al., 2014).

These results were compared with cookies from three conventional brands that are widely established in the Brazilian market, with two of them from the fitness segment, and the lowest protein content (5.66-6.66\%) and comparable fibre values (3.66-8.99\%) were found in two of them.

The BFC showed the lowest $\mathrm{A}_{\mathrm{w}}$, which evaluate the amount of water available in the sample as a medium conducive to enzymatic reactions and proliferation of microorganisms. None of the cookies presented the minimum value for the propitious multiplication of microorganisms (Rifna et al., 2019). The $A_{w}$ parameter also affects the physical properties of foods and is an important parameter for evaluating product sensory quality (Katz \& Labuza, 1981), especially of cookies that require a characteristic texture.

During the monitored period, no oxidation products were detected, as determined by the peroxide value, that quantify the oxidative deterioration of foods, responsible for the decrease of the sensory quality and reduction of the shelf life of the products (Cecchi, 2015).

\subsection{Sensory evaluation}

. The BFM presented the best performance, with a score of approximately 7 ('moderately liked'). The BFP presented the lowest acceptability, indicated by scores between 5 and 6 in all aspects (Dutcosky, 2019). However, an overall acceptability that is greater than 5 indicates good quality, which can be improved by adding components to increase palatability. Figure 1 shows the results of the cookie acceptance survey.

\subsection{Colour and instrumental texture}

The results of colour and instrumental texture are presented in Table 2.

The colour analysis was performed only to characterise the elaborated cookies. The values of $\mathrm{a}^{*}$ and $\mathrm{b}^{*}$ indicate a yellow hue; $\mathrm{L}^{\star}$ indicates a light colour; $\mathrm{C}^{\star}$ and $\mathrm{Hue}^{\circ}$ indicate a grayish-yellow hue (except for BFM, that presents the highest values, indicating an intense colour). The ANOVA indicated a similarity in the tone of these cookies. These results show a correlation between the colour of the pulse flours and the cookies after preparation.

The BFC and BFM showed the highest hardness values, in agreement with the moisture results. Hardness is an important texture parameter for cookies and is directly associated with food acceptability and quality as consumers anticipate crunchy and hard products.

\subsection{Mineral composition}

In general, all formulations presented expressive levels of essential metals for the organism, such as $\mathrm{Ca}, \mathrm{P}, \mathrm{K}$ and $\mathrm{Mg}$, which are metals that play important roles in body metabolism (Gropper et al., 2017). The ANOVA indicates no difference in means ( $p>0.05$ ) between the formulations (except for $\mathrm{Cu}$ and $\mathrm{Mn}$ ), indicating that, in general, they have a similar mineral profile. Figure 2 presents the results of the mineral composition of the cookies.

The contents of $\mathrm{P}, \mathrm{Mg}, \mathrm{K}, \mathrm{Fe}$ and $\mathrm{Ca}$ in the three formulations are higher than those obtained by Rao et al. (2018) for cookies prepared from sorghum cultivars. The $\mathrm{Al}$ and $\mathrm{Ba}$ concentrations are below the detection limits ( 3 and $0.04 \mathrm{ng} \mathrm{g}^{-1}$, respectively) and have been removed from the graph. These metals have no known biological role (Kravchenko et al., 2014; Exley, 2013).

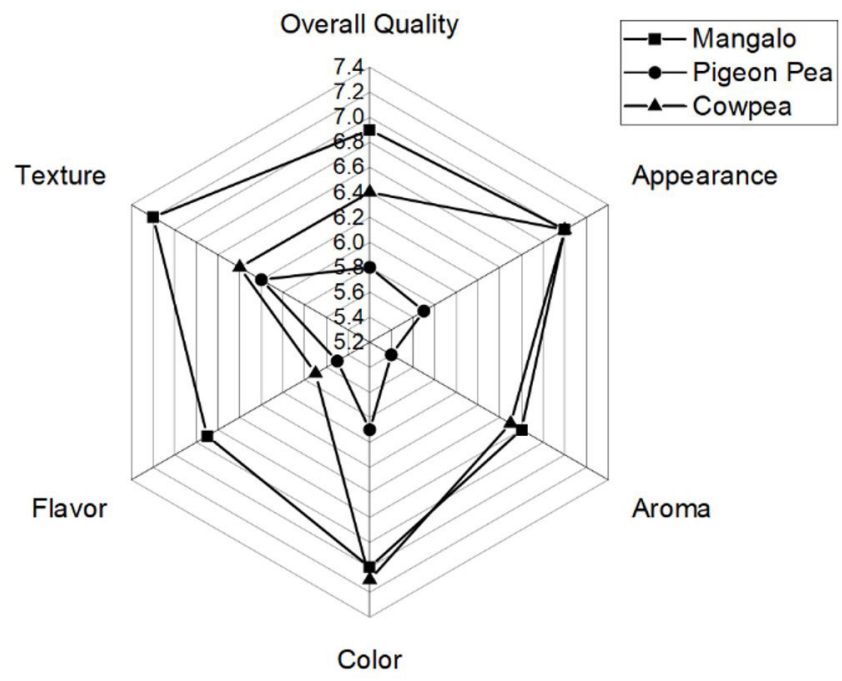

Figure 1. Overall result of the sensory analysis $(n=60)$ of cookies made from legume flours.

Table 2. Results of colourimetric determination (dimensionless; $n=3$ ) and hardness ( $g ; n=6)$.

\begin{tabular}{|c|c|c|c|c|c|c|}
\hline \multirow{2}{*}{ Cookie } & \multicolumn{5}{|c|}{ Colour } & \multirow{2}{*}{$\begin{array}{c}\text { Texture } \\
\text { Hardness }\end{array}$} \\
\hline & $\mathrm{L}^{*}$ & $a^{*}$ & $b^{*}$ & $C^{*}$ & $\mathrm{Hue}^{\mathrm{o}}$ & \\
\hline $\mathrm{BFC}$ & $56.98 \pm 1.84^{b}$ & $3.26 \pm 0.32^{\mathrm{b}}$ & $22.49 \pm 0.80^{\mathrm{b}}$ & $22.73 \pm 0.75^{b}$ & $81.74 \pm 1.08^{b}$ & $3,479 \pm 600^{a}$ \\
\hline BFP & $53.62 \pm 1.79^{b}$ & $1.13 \pm 0.21^{\mathrm{c}}$ & $23.67 \pm 1.74^{\mathrm{b}}$ & $23.70 \pm 1.72^{b}$ & $87.23 \pm 0.66^{c}$ & $2,314 \pm 244^{b}$ \\
\hline BFM & $65.76 \pm 1.40^{\mathrm{a}}$ & $-0.31 \pm 0.06^{\mathrm{a}}$ & $30.07 \pm 1.87^{\mathrm{a}}$ & $30.07 \pm 1.87^{\mathrm{a}}$ & $90.62 \pm 0.05^{\mathrm{a}}$ & $3,134 \pm 659^{a}$ \\
\hline
\end{tabular}

Means followed by equal letters in the columns do not differ by Tukey test, at a significance level of $5 \%$; values represent means \pm standard deviation. 

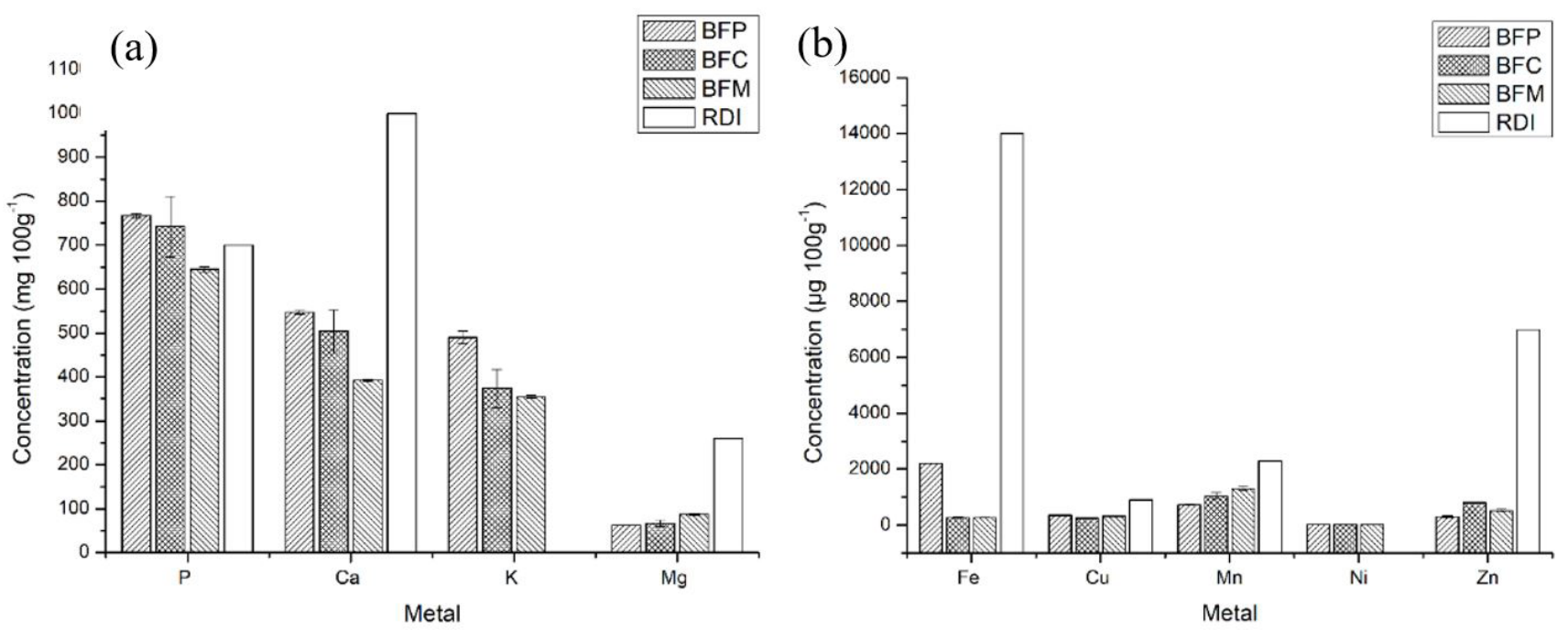

Figure 2. The bar graph of the concentration of the (a) macro (mg $100 \mathrm{~g}^{-1} ; \mathrm{n}=3$ ) and (b) microelements $\left(\mu \mathrm{g} 100 \mathrm{~g}^{-1} ; \mathrm{n}=3\right)$ in cookies made with legume flours and the respective values of recommended daily intake (RDI) (mg/per day) for comparison.

Table 3. Derringer \& Suich individual and overall desirabilities functions (D).

\begin{tabular}{|c|c|c|c|c|c|c|c|c|c|c|c|c|c|c|c|}
\hline & $\mathrm{Ca}$ & $\mathrm{K}$ & $\mathrm{Mg}$ & $\mathrm{Fe}$ & $\mathrm{Zn}$ & $\mathrm{Cu}$ & $\mathrm{Mn}$ & $\mathrm{Ni}$ & Fibre & Protein & Moisture & Lipid & Ash & $\begin{array}{c}\mathrm{D}- \\
\text { micros- } \\
\text { macros }\end{array}$ & $\begin{array}{c}\mathrm{D}- \\
\text { macros }\end{array}$ \\
\hline \multirow{2}{*}{$\mathrm{BFC}$} & 0.647 & 0.401 & 0.400 & 0.660 & 0.779 & 0.310 & 0.538 & 0.289 & 0.480 & 0.561 & 0.852 & 0.556 & 0.601 & 0.519 & 0.598 \\
\hline & 0.452 & 0.211 & 0.217 & 0.424 & 0.785 & 0.189 & 0.367 & 0.073 & 0.165 & 0.539 & 0.857 & 0.595 & 0.625 & 0.345 & 0.490 \\
\hline BFM & 0.223 & 0.256 & 0.674 & 0.493 & 0.351 & 0.526 & 0.743 & 0.538 & 0.317 & 0.525 & 0.353 & 0.585 & 0.318 & 0.426 & 0.405 \\
\hline \multirow{3}{*}{ BFP } & 0.685 & 0.677 & 0.219 & 0.260 & 0.166 & 0.678 & 0.163 & 0.550 & 0.463 & 0.422 & 0.270 & 0.437 & 0.615 & 0.383 & 0.427 \\
\hline & 0.667 & 0.625 & 0.219 & 0.260 & 0.072 & 0.655 & 0.136 & 0.549 & 0.650 & 0.422 & 0.255 & 0.569 & 0.610 & 0.365 & 0.4756 \\
\hline & 0.664 & 0.692 & 0.237 & 0.260 & 0.074 & 0.707 & 0.156 & 0.785 & 0.752 & 0.324 & 0.266 & 0.495 & 0.625 & 0.381 & 0.457 \\
\hline
\end{tabular}

Table 4. One-way ANOVA and Student's t-test for independent samples with Bonferroni's adjustment based on overall desirabilities functions (D) obtained including macroconstituents and microconstituents and only macroconstituents.

\begin{tabular}{|c|c|c|c|c|c|c|c|c|c|c|}
\hline \multirow[b]{2}{*}{ Source } & \multirow[b]{2}{*}{$\begin{array}{l}\text { Sum of } \\
\text { squares }\end{array}$} & \multirow{2}{*}{\multicolumn{2}{|c|}{ Mean square }} & \multicolumn{3}{|c|}{ Macroconstituents and Microconstituents } & \multicolumn{4}{|c|}{ Only Macroconstituents } \\
\hline & & & & $\begin{array}{l}\text { Degree of } \\
\text { freedom }\end{array}$ & p value & $\begin{array}{l}\text { Sum of } \\
\text { squares }\end{array}$ & \multicolumn{2}{|c|}{ Mean square } & $\begin{array}{l}\text { Degree of } \\
\text { freedom }\end{array}$ & $p$ value \\
\hline $\begin{array}{l}\text { Between } \\
\text { sample } \\
\text { types }\end{array}$ & 0.00571 & \multicolumn{2}{|c|}{0.00285} & 2 & 0.401 & 0.055706 & \multicolumn{2}{|c|}{0.027853} & 2 & $0.00407^{*}$ \\
\hline $\begin{array}{l}\text { Within } \\
\text { sample } \\
\text { type }\end{array}$ & 0.0160 & \multicolumn{2}{|c|}{0.00267} & 6 & - & 0.0106 & \multicolumn{2}{|c|}{0.00176} & 6 & - \\
\hline \multirow[t]{2}{*}{ Total } & 0.0217 & \multicolumn{2}{|l|}{-} & 8 & - & 0.0663 & \multicolumn{2}{|c|}{-} & 8 & - \\
\hline & $\begin{array}{c}\text { Mean Group } \\
1\end{array}$ & $\begin{array}{c}\text { Mean Group } \\
2\end{array}$ & $\mathrm{t}$-value & p-value & $\begin{array}{c}\text { Bonferroni's } \\
\alpha^{\prime}\end{array}$ & $\begin{array}{c}\text { Mean } \\
\text { Group } 1\end{array}$ & $\begin{array}{c}\text { Mean } \\
\text { Group } 2\end{array}$ & t-value & $\mathrm{p}$-value & $\begin{array}{c}\text { Bonferroni's } \\
a^{\prime}\end{array}$ \\
\hline $\begin{array}{l}\mathrm{BFC} \times \\
\mathrm{BFM}\end{array}$ & 0.438 & 0.408 & 0.589 & 0.588 & 0.0169 & 0.558 & 0.365 & 4.867 & $0.00823^{\star}$ & 0.0169 \\
\hline $\begin{array}{l}\mathrm{BFC} \times \\
\mathrm{BFP}\end{array}$ & 0.438 & 0.376 & 1.213 & 0.291 & 0.0169 & 0.558 & 0.453 & 2.830 & 0.0473 & 0.0169 \\
\hline $\begin{array}{l}\text { BFM } \times \\
\text { BFP }\end{array}$ & 0.408 & 0.376 & 2.848 & 0.0464 & 0.0169 & 0.365 & 0.453 & 3.596 & 0.0228 & 0.0169 \\
\hline
\end{tabular}

${ }^{*}$ Significant value. 
Figure 2 also shows the recommended daily intake (RDI) values for some elements reported by Brasil (2005). When comparing the RDI with the levels of minerals present in cookies, was verified that they present a high nutritional capacity for an adult, contributing mainly with $\mathrm{Ca}$ and $\mathrm{P}$.

\subsection{Desirability data analysis}

Calculated desirabilities functions of evaluated parameters, according to Derringer \& Suich (1980), are summarised in Table 3. Statistical comparison carried out by ANOVA and Student's t-test (Table 4), using overall desirabilities functions obtained revealed non-significant differences between desirabilities of the BFC, BFM and BFP at 95\% confidence level.

On the other hand, statistical comparison carried out by ANOVA and Student's t-test (Table 4), using overall desirabilities functions based only on macroconstituents, revealed significant differences between BFC, BFM and BFP. Further analysis with Student's t-test for independent samples with Bonferroni's adjustment showed specific significant difference between macroconstituents of the BFC and BFM at 95\% confidence level.

In summary, significant differences were identified between the optimal characteristics of the BFC and BFM samples when considering only the macroconstituents (fibre, proteins, lipids, moisture and ash). In this way, the BFC cookie can be considered as superior in relation to the desirable characteristics for the investigated quality parameters.

\section{Conclusions}

It can be concluded that pulse flours can be a good alternative for the formulation of cookies, since the results indicate that the prepared cookies are a good source of protein, fibre, carbohydrates and essential minerals (mainly $\mathrm{K}, \mathrm{Ca}$ and $\mathrm{P}$ ), improving the nutritional quality of the final product. The desirability data demonstrated better performance of the BFP type cookie compared with the other two formulations (BFP and BFM), which, associated with satisfactory acceptability, shows a high commercial potential.

\section{Acknowledgements}

The authors are grateful to the Fundação de Amparo à Pesquisa do Estado da Bahia (FAPESB, Brazil), Pro-Rectory for Research, Graduate and Innovation (PRPGI-IFBA) and the Instituto Federal da Bahia (IFBA, Brazil) for providing grants and fellowships and for their financial support.

\section{References}

Afshin, A., Micha, R., Khatibzadeh, S., \& Mozaffarian, D. (2014). Consumption of nuts and legumes and risk of incident ischemic heart disease, stroke, and diabetes: a systematic review and meta-analysis. The American Journal of Clinical Nutrition, 100(1), 278-288. http:// dx.doi.org/10.3945/ajcn.113.076901. PMid:24898241.

Aggarwal, M., Bozkurt, B., Panjrath, G., Aggarwal, B., Ostfeld, R. J., Barnard, N. D., Gaggin, H., Freeman, A. M., Allen, K., Madan, S., Massera, D., \& Litwin, S. E. (2018). Lifestyle modifications for preventing and treating heart failure. Journal of the American
College of Cardiology, 72(19), 2391-2405. http://dx.doi.org/10.1016/j. jacc.2018.08.2160. PMid:30384895.

American Oil Chemists' Society - AOCS. (2017). Official methods and recommended practices of the AOCS (7th ed.). Champaign: AOCS.

Association of Official Agricultural Chemists - AOAC. (2005). Official methods of analysis of the Association of Official Agriculture Chemists (18th ed.). Gaithersburg: AOAC International.

Bessada, S. M. F., Barreira, J. C. M., \& Oliveira, M. B. P. P. (2019). Pulses and food security: Dietary protein, digestibility, bioactive and functional properties. Trends in Food Science \& Technology, 93, 53-68. http://dx.doi.org/10.1016/j.tifs.2019.08.022.

Brasil, Agência Nacional de Vigilância Sanitária - ANVISA. (1978, July 24). Aprova normas técnicas especiais, do Estado de São Paulo, revistas pela CNNPA, relativas a alimentos (e bebidas), para efeito em todo território brasileiro (Resolução CNNPA nº 12, de 1978). Diário Oficial [da] República Federativa do Brasil.

Brasil, Agência Nacional de Vigilância Sanitária - ANVISA. (2005, September 25). Regulamento técnico sobre a Ingestão Diária Recomendada (IDR) de proteína, vitaminas e minerais (Resolução $\mathrm{n}^{\circ}$ 269, de 22 de setembro de 2005). Diário Oficial [da] República Federativa do Brasil.

Carbone, J. W., \& Pasiakos, S. M. (2019). Dietary protein and muscle mass: translating science to application and health benefit. Nutrients, 11(5), 1136. http://dx.doi.org/10.3390/nu11051136. PMid:31121843.

Cauvain, S., \& Young, L. (2008). Bakery food manufacture and quality: water control and effects (2nd ed.). Hoboken: Wiley-Blackwell. http:// dx.doi.org/10.1002/9781444301083.

Cecchi, H. M. (2015). Fundamentos teórios e práticos em análises de alimentos (2. ed. rev.). Campinas: Editora UNICAMP.

Cheng, Y. F., \& Bhat, R. (2016). Functional, physicochemical and sensory properties of novel cookies produced by utilizing underutilized jering (Pithecellobium jiringa Jack.) legume flour. Food Bioscience, 14, 54-61. http://dx.doi.org/10.1016/j.fbio.2016.03.002.

Davidson, I. (2018). Biscuit, cookie and cracker production: process, production and packaging Equipment (1st ed., Chap. 1). Massachusetts: Academic Press.

Derringer, G., \& Suich, R. (1980). Simultaneous optimization of several response variables. Journal of Quality Technology, 12(4), 214-219. http://dx.doi.org/10.1080/00224065.1980.11980968.

Dutcosky, S. D. (2019) Análise sensorial de alimentos (5. ed.). Curitiba: Champagnat.

European Union, European Commission. (2006, December 30). Regulation (EC) No 1924/2006 of the European Parliament and of the Council of 20 December 2006 on nutrition and health claims made on foods. Official Journal of the European Union.

Exley, C. (2013). Human exposure to aluminium. Environmental Science. Processes \& Impacts, 15(10), 1807-1816. http://dx.doi.org/10.1039/ C3EM00374D. PMid:23982047.

Gropper, S. S., Smith, J. L., \& Carr, T. P. (2017). Advanced nutrition and human metabolism (7th ed.). Boston: Cengage Learning.

Howe, S. M., Hand, T. M., \& Manore, M. M. (2014). Exercise-trained men and women: role of exercise and diet on appetite and energy intake. Nutrients, 6(11), 4935-4960. http://dx.doi.org/10.3390/ nu6114935. PMid:25389897.

Instituto Adolfo Lutz - IAL. (2008). Métodos físico-químicos para análises de alimentos (4. ed.). São Paulo: IAL.

Katz, E. E., \& Labuza, T. P. (1981). Effect of water activity on the sensory crispness and mechanical deformation of snack food 
products. Journal of Food Science, 46(2), 403-409. http://dx.doi. org/10.1111/j.1365-2621.1981.tb04871.x.

Kaur, M., Singh, V., \& Kaur, R. (2017). Effect of partial replacement of wheat flour with varying levels of flaxseed flour on physicochemical, antioxidant and sensory characteristics of cookies. Bioactive Carbohydrates and Dietary Fibre, 9, 14-20. http://dx.doi.org/10.1016/j. bcdf.2016.12.002.

Kravchenko, J., Darrah, T. H., Miller, R. K., Lyerly, H. K., \& Vengosh, A. (2014). A review of the health impacts of barium from natural and anthropogenic exposure. Environmental Geochemistry and Health, 36(4), 797-814. http://dx.doi.org/10.1007/s10653-014-96227. PMid:24844320.

Ledikwe, J. H., Blanck, H. M., Kettel Khan, L., Serdula, M. K., Seymour, J. D., Tohill, B. C., \& Rolls, B. J. (2006). Dietary energy density is associated with energy intake and weight status in US adults. The American Journal of Clinical Nutrition, 83(6), 1362-1368. http:// dx.doi.org/10.1093/ajcn/83.6.1362. PMid:16762948.

Marques, G. A., São José, J. F. B., Silva, D. A., \& Silva, E. M. M. (2015). Whey protein as a substitute for wheat in the development of no added sugar cookies. Lebensmittel-Wissenschaft + Technologie, 67, 118-126. http://dx.doi.org/10.1016/j.lwt.2015.11.044.
Park, J., Choi, I., \& Kim, Y. (2015). Cookies formulated from fresh okara using starch, soy flour and hydroxypropyl methylcellulose have high quality and nutritional value. Lebensmittel-Wissenschaft + Technologie, 63(1), 660-666. http://dx.doi.org/10.1016/j.lwt.2015.03.110.

Prasad, K. N., \& Bondy, S. C. (2019). Dietary fibers and their fermented short-chain fatty acids in prevention of human diseases. Bioactive Carbohydrates and Dietary Fibre, 17, 100170. http://dx.doi. org/10.1016/j.bcdf.2018.09.001.

Rao, B., Kulkarni, D., \& Kavitha, C. (2018). Study on evaluation of starch, dietary fiber and mineral composition of cookies developed from 12 Sorghum cultivars. Food Chemistry, 238, 82-86. http://dx.doi. org/10.1016/j.foodchem.2016.12.069. PMid:28867105.

Rifna, E. J., Singh, S. K., Chakraborty, S., \& Dwivedi, M. (2019). Effect of thermal and non-thermal techniques for microbial safety in food powder: recent advances. Food Research International, 126, 108654. http://dx.doi.org/10.1016/j.foodres.2019.108654. PMid:31732065.

Shahidi, F., \& Ambigaipalan, P. (2015). Phenolics and polyphenolics in foods, beverages and spices: Antioxidant activity and health effects: a review. Journal of Functional Foods, 18, 820-897. http://dx.doi. org/10.1016/j.jff.2015.06.018.

Wrigley, C., Corke, H., Seetharaman, K., \& Faubion, J. (2016). Encyclopedia of food grains (2nd ed.). Cambridge: Academic Press. 